Relations industrielles

Industrial Relations

\title{
Towards a Social Regulation of the Global Firm? Introduction
}

\section{Gregor Murray et Gilles Trudeau}

Volume 59, numéro 1, hiver 2004

Équité, efficience, éthique ? La régulation sociale de l'entreprise mondialisée

URI : https://id.erudit.org/iderudit/009125ar

DOI : https://doi.org/10.7202/009125ar

Aller au sommaire du numéro

Éditeur(s)

Département des relations industrielles de l'Université Laval

ISSN

0034-379X (imprimé)

1703-8138 (numérique)

Découvrir la revue

Citer cet article

Murray, G. \& Trudeau, G. (2004). Towards a Social Regulation of the Global Firm? Introduction. Relations industrielles / Industrial Relations, 59(1), 15-25. https://doi.org/10.7202/009125ar

Tous droits réservés (c) Département des relations industrielles de l'Universite Laval, 2004
Ce document est protégé par la loi sur le droit d'auteur. L'utilisation des services d’Érudit (y compris la reproduction) est assujettie à sa politique d'utilisation que vous pouvez consulter en ligne.

https://apropos.erudit.org/fr/usagers/politique-dutilisation/ 


\title{
Towards a Social Regulation of the Global Firm?
}

\section{Introduction}

\author{
Gregor MurRay \\ Gilles Trudeau
}

Multinational firms are both a motor and a transmission belt for the internationalization of economic and social relations. The economic development and even the prosperity of most nations seem to be inextricably linked to the scope and intensity of the activities of the approximately 65,000 multinational firms and their 850,000 foreign affiliates operating in one area or another of the planet. ${ }^{1}$ The wealth of nations is thus tied to their capacity to partake of the international trading system by attracting foreign direct investment and finding their niches of competitive advantage within an increasingly global economy.

Multinational firms are, of course, not a new phenomenon. To cite the example of Canada, from the earliest exploration of its territory and the opening of its frontiers and provinces by such international undertakings as the Hudson's Bay Company, to the creation of Canadian branch plants of U.S. and British firms under the tariff protections of the late nineteenth and early twentieth centuries, to the increasing interpenetration of the Canadian and U.S. economies in the latter decades of the twentieth century, the activities of multinational companies in Canada have been a vector of its economic and social development, making it one of the most open and prosperous economies in the globe.

Yet, as witnessed by the proliferation of the globalization lexicography (multinational, international, transnational, global), the nature of the so called multinational company appears to be changing in important ways. Earlier generations of multinational corporate structure are giving way

- Murray, G., and G. Trudeau, Centre de recherche interuniversitaire sur la mondialisation et le travail (CRIMT - Université de Montréal, Université Laval, HEC Montréal, <www. crimt.org>); professors at the School of Industrial Relations (gregor.murray@umontreal. ca) and the Faculty of Law (gilles.trudeau@umontreal.ca), Université de Montréal.

1. This estimation is drawn from The World Commission on the Social Dimension of Globalization (2004: 33). 
to new types of structures (see, for example, Bartlett and Ghoshal 2002; Dicken 2003) and this raises challenges for practitioners and scholars of industrial relations.

The original predominant model for multinational firms was that of a "portfolio of national businesses". In essence, a multinational company decentralized its operations in order to ensure proximity and sensitivity to different national markets. Typically, it took the form of a "National Business Inc.", which allowed for the possibility of a distinct and sometimes even autonomous identity for the firm in each of its national locations, making it much more sensitive to the host country environment and its policy tools. Indeed, such firms were an integral part of the historical development of national industrial relations traditions and policies.

A subsequent model of international corporate structure was more centralized in nature. Typically, they were especially successful national corporations which drove their overseas activities and comparative advantage through technology transfers and a fairly high degree of centralized control. Although they were probably less sensitive to national policy environments in host countries, they did offer high quality employment and considerable potential for the diffusion of economic and organizational innovation from country of origin to host countries and, sometimes, through reverse diffusion, from host country to country of origin. The increasing importance of such organizational structures from the 1960s onwards raised several issues for labour policies. To what degree were such firms impervious to national domestic employment practices? For example, would rough and tough, anti-union firms originating in the United States of America adopt similar practices in other national contexts or adapt their policies to these different institutional contexts? Indeed, much research effort was dedicated to the employment policy motivations of such firms in the 1970s and 1980s. Given the relative centralization of this new type of firm, there was also an increasing attention to the role of international mechanisms to influence the behaviour of these firms. Thus a new generation of research was focused on the role of international bodies in doing research on and establishing guidelines for acceptable behaviour on the part of these firms, as in the case of the United Nations, the International Labour Organization, the OECD and international union bodies such as the International Confederation of Free Trade Unions. ${ }^{2}$

However, a number of drivers of globalization have fundamentally transformed the dynamics of these earlier corporate structures into newer

2. For example, see Gunter (1972), Kujawa (1975), and Banks and Stieber (1977) for academic research in this area. 
types of transnational or global firms. These include the increasing integration of world regional markets (as in NAFTA, the EU, etc.), the decline of commercial barriers (the WTO), the dramatic rise in foreign direct investment, the much greater mobility of capital and of access to capital markets, the need and possibility to exploit scale efficiencies and knowledge flow through new information and communications technologies, and the possibility of exploiting cost and knowledge advantages. In some cases, corporate control remains highly centralized in a single corporate centre, or is diffused in multiple divisions or clusters, but the firm is in new ways truly global because of its ability to propel innovation throughout the "value chain" through processes and procedures, such as benchmarking and information control systems.

Another new corporate form is more complex and diffuse. As older hierarchical forms give way to the flatter network architectures of global production systems, it is sometimes difficult to identify a single, decision-making centre. Bartlett and Ghoshal (2002) see such transnational structures as dispersed, interdependent and specialized in which there are differentiated contributions by national or local units to integrated worldwide operations. Similarly, Dicken (2003) writes of "integrated networks". Such global production systems are increasingly characterized by a multiplicity of inter-firm relationships and a blurring of organizational boundaries. National businesses and/or local business units must then either bid for product and service mandates that allow them to aspire beyond the domestic market, as in the transnational firm structures, or to carve out an entirely new role as a nodal point in more complex organizational and communications networks.

The emergence of such global firms raises entirely new questions for the regulation of their activities as regards work and employment. For some observers, the market is so complex and so dynamic that a laisser faire approach should suffice. According to this sanguine view of the autonomous logic of economic regulation, global firms are engaged in a desperate search for comparative advantage in both local and international markets. They are therefore likely to pay a premium, above and beyond prevailing local conditions, for knowledge resources and high performance in a bid to retain, motivate and mobilize their workforce and their suppliers. Indeed, this view is consistent with much international evidence to the effect that such firms are more frequently the drivers of innovation and offer better terms and conditions than what would otherwise be the case in local markets. This approach also gives ideological comfort to a neo-liberal political view to the effect that markets are best left unregulated and that state and union efforts to dictate the course of economic development are more likely to result in perverse effects. 
A more alarmist scenario, akin to a classic "immiseration" thesis, suggests that market regulation alone is likely to precipitate a downward spiral in the terms and conditions of employment. Firms will relocate where they can obtain a comparable output for lower factor cost. Countries, territories and communities are thereby condemned to engage in social undercutting or "dumping" in order to attract the jobs which, alone, can ensure their economic and social viability. Moreover, as is the case with most less developed economies, the virtuous circle approach is less likely to hold sway in the presence of vast informal sectors of unemployed and underemployed workers. That is why the actual experience of many workers in the internationalized industries of developing economies (for example, in Mexico) has been one of falling real wages in a context of the increasing penetration of global production systems and the liberalization of trading relations.

Not surprisingly, a third approach-one that is certainly in keeping with the analytical traditions of industrial relations - suggests that there exists considerable scope for social regulation in this process. To paraphrase one participant in a consultation exercise of the recent World Commission on the Social Dimensions of Globalization (2004), what's the use of the falling cost of the price of children's shoes if the children's parents lose their source of livelihood in the process? According to this social regulation approach, if some combination of the intervention of state and non-state actors is required to influence the behaviour of global firms, the problem is dynamic and qualitative because the relevance of the older forms of social regulation is increasingly open to question. We therefore need to look to at some combination of national and international political institutions, direct or indirect ("hard" or "soft") legislative framing, the actions of trade unions and civil society groups and, indeed, the direct pressure exercised by consumers preoccupied with the ethical and planetary ramifications of their decisions.

Such is the point of departure for this special issue of Relations industrielles/Industrial Relations. Drawing on a range of original contributions, it seeks to set out some of the pathways for thinking about the increasingly important phenomenon of the social regulation of work and employment in global firms. Under the auspices of its Social Sciences and Humanities Research Council's Major Collaborative Research Initiatives (SSHRCMCRI) project on rethinking institutions for work and employment in a global era, the Inter-University Research Centre on Globalization and Work's (CRIMT - Université de Montréal, Université Laval, HEC Montréal), in cooperation with the Canadian Workplace Research Network (CWRN), issued a call for papers to be presented at its May 2003 international symposium on Corporate Codes of Conduct and the Social Regulation of the 
Global Firm: Equity, Efficiency or Ethics? $?^{3}$ Organized by CRIMT and held at HEC Montreal, the symposium featured a range of original papers and contributions, stemming from an initial selection in response to our call for papers. The articles collected in this special issue of RI/IR are those that were subsequently reviewed by external referees and accepted for publication. ${ }^{4}$ In the remainder of this introduction, we set out and assess some of the analytical pathways identified in these contributions.

The evolution of the global firm and its new organizational forms described above highlight the limits of traditional mechanisms of social regulation in this new context of economic internationalization. National industrial relations actors, particularly unions and the State, have hitherto generally associated the regulation of work and employment with national institutions such as labour legislation and collective bargaining. However, by its very nature, the global firm now organizes its production and services on an international basis, in which national boundaries seem entirely less relevant. The resulting fragility of traditional modes of social regulation can be linked to three factors.

First, above and beyond the competition between states to attract foreign direct investment, it should be emphasized that the global firm is subject to highly fragmented forms of social regulation, the content of which can vary from one place to another, according to the geography of its investment strategies. There is not a global system of social regulation affecting simultaneously all of the component parts of a global firm and making it responsible for all of its activities.

3. Financial, organizational and material support for this symposium was provided by the Social Sciences and Humanities Research Council of Canada, the Fonds québécois de recherche sur la société et la culture, Human Resources and Development Canada's Labour-Management Partnerships Program HRDC, the Ministère des Finances, de l'Économie et de la Recherche du Gouvernement du Québec, Relations Industrielles/ Industrial Relations, HEC Montreal, the Law Commission of Canada, the Canadian Workplace Research Network (CWRN) and the Centre de recherche interuniversitaire sur la mondialisation et le travail (CRIMT - Université de Montréal, Université Laval, HEC Montreal). We particularly wish to thank Adelle Blackett, Christian Lévesque, Judith Paquet, Nicolas Roby, Guylaine Vallée and Pierre Verge for their work on the academic organizing committee and in the initial selection of the papers to be presented at the Symposium.

4. A second stream of invited papers, each surveying key issues and/or geographical areas of the overall theme of the social regulation of global firms, will soon be published in book form. 
Second, given the pressures of international competition and the possibilities unleashed by technological innovation, the Fordist model of the firm, which gave rise to previous forms of social regulation, is giving way to a more decentralized organization of production for which the outsourcing of activities is a central tenet. Full-time, permanent waged labour no longer occupies the central role that it once did. Instead, myriad forms of precarious and atypical employment have taken its place and international outsourcing remains a constant possibility.

Finally, from the 1970s onwards, the role of the State in the regulation of the economy and the precepts of the welfare state have been challenged in a move to emphasize the importance of individual autonomy and market forces as a basis for social regulation. This neo-liberal ideology has spread rapidly throughout the planet, notably as a result of the internationalization of the economy and the role of the international institutions associated with the Bretton-Woods agreements. This phenomenon has weakened the classic mechanisms of social regulation at both national and international levels and challenged the legitimacy of any form of regulation other than that of the market.

This weakening of traditional forms of social regulation has sparked a profound rethinking of the nature of such regulation and the role of both such instruments and the traditional actors of the regulation of work and employment, particularly as regards the global firm. The Fordist era relied on a model of social regulation centred on the nation state. State labour law, to which other modes of social regulation (unions and collective bargaining) were generally subordinated, played a hegemonic role. The internationalization of the economy and the development of the global firm are heralding a new social order, the nature of which remains to be defined but in which national state labour law is likely to have lost its pride of place.

A variety of solutions and proposals have been advanced with regard to this new social order. Several new forms of social regulation can already be discerned. Sometimes national and sometimes international, stemming from positive law or more private initiatives, both formal and informal, what is most striking is that they are not likely to replace more traditional mechanisms for the regulation of work and employment in the short term. Rather, they complement them and sometimes enhance their efficacy. The result, and this is much in evidence in this special issue of $R I / I R$, is a complex mosaic of different actors and actions seeking the social regulation of the global firm. The particular notion of social regulation employed here concerns all forms of intervention, other than those associated with the interaction of market forces, which seek to influence the behaviour of firms. 
State labour law, be it national or international, continues to play a key role. Its nature and contribution, however, are changing. The article by André Sobczak shows how the regulation of work and labour relations increasingly uses the techniques of commercial and consumer law. This innovation offers manifest advantages, notably in the ability to ensure a degree of social protection to the network of collaborators of the firm who, by and large, remain economically subordinated to it, but who traditionally have been completely excluded from the realm of labour law. In the same way, this new use of other legal techniques opens up the possibility to legalize collective action on the part of other stakeholders in the firm, often in order to compensate for the deficiencies of traditional forms of worker collective action in a global firm. Despite these advantages, it is important to keep in mind that commercial and consumer law do not respond to the same imperatives. Only labour law has as a central vocation the protection of workers. Even if it is useful, indeed essential, that labour law builds bridges with these other branches of positive law, labour law alone is likely to be able to play a role in mediating the divergent interests of capital and labour and this role is largely a foreign territory for these other branches of law.

For many, international labour law is an integral part of the path to enhanced social justice in the current context of economic globalization. While some of its best known manifestations remain imprisoned in the logic of national states and international relations, others are pursuing techniques hitherto ignored or untried to bring both national states and global firms to respect certain fundamental dimensions of social justice. For example, in the context of treaties enabling regional economic integration, as in Europe and North America, we can observe the creation of mechanisms, exhibiting greater or lesser degrees of coercion, to achieve the harmonization of social regulation. While the nature and impact of these mechanisms vary from one experience to another, they do offer innovative attempts to oversee the behaviour of transnational firms. Even international state organizations, such as the International Labour Organization (ILO) and the Organization for Economic Cooperation and Development (OECD), are working to develop and implement international instruments able to subject the global firm to fundamental principles of social justice.

In this respect, Isabelle Duplessis's article highlights how the ILO Declaration on Fundamental Principles and Rights at Work and its Followup, adopted in 1998 as a response to the challenges of globalization for social regulation, is now becoming a universal point of reference on the subject. This initiative was born in controversy, notably because of the purely declaratory nature of the Declaration which made it more like an instrument of "soft law", void of any judicial obligations or constraints. How then could such a timid initiative on the part of the International Labour 
Organization come to be seen as efficacious and even compensate for the 1994 failure at Marrakech of those seeking the inclusion of a social clause in the founding treaty of the World Trade Organization (WTO)? The answer lies in the nature of the emerging model of social regulation. This model does not rely solely on the legal efficacy of its instruments but also, indeed preponderantly, on the scope that it leaves for the actions of pressure groups and the mechanisms to which they have recourse in order to achieve the same common objectives. That is what the ILO Declaration seems to be seeking to achieve. In essence, it puts forward four fundamental rights that are identified as principles that cannot be ignored or set aside not only by national laws, but also by global firms in their codes of conduct and other forms of unilateral engagements.

In addition to the hitherto quite timid renewal of national and international legal instruments, social regulation in the context of globalization has, in recent times, more often relied on mechanisms that call on the social responsibility of firms and their role as "global citizens". This phenomenon generally takes the form of voluntary initiatives, particularly with regard to social and environmental concerns, and tends to go beyond the minimum obligations set out in law. In this way, it is a question of private or self-regulation and the ethical standards of global firms. The article by Corinne Gendron, Alain Lapointe and Marie-France Turcotte suggests that this narrative is not entirely accurate. It is argued that the kinds of corporate initiatives in the area of social responsibility, currently observed on a global scale, are much more of a response to an environment that corporate actors see as constraining. These initiatives are strategies deployed by firms in order to seek a renewed legitimacy in a context of emerging forms of social regulation. In as much as firms always act in their own interests, it seems likely that corporate codes of conduct are a response on the part of the most far sighted of these actors to the complex and constraining global regulatory framework that they see taking shape.

This "realist" vision of the self-regulatory capacity of global firms is certainly reinforced by Penelope Simons' study of the voluntary instruments of social regulation adopted by four multinational firms in the petroleum industry. Her analysis raises basis questions about the efficacy of such instruments of autonomous regulation, notably with regard to their ability to ensure the respect of fundamental human rights in overseas undertakings. Overall, these instruments lack sufficient precision and specificity as regards the rights that they recognize. Similarly, they do not guarantee credible and independent mechanisms to ensure their implementation. However, the efficacy of these instruments would be greatly improved if they were supplemental to other forms of independent regulation. In terms of content, these mechanisms should espouse fundamental and universally recognized 
standards and entail criteria that can be empirically verified with regard to compliance. As concerns the monitoring of their implementation, it is essential that this be done by organizations that are independent of the firms whose behaviour is being monitored. These recommendations highlight the complementary nature of the different mechanisms of social regulation which are required on a global scale and the need to construct bridges between them. Public instruments will only really be useful if they take account of and are linked to the mechanisms and actions of transnational private organizations. By the same token, private initiatives will only acquire legitimacy if they are able to meet minimum conditions as regards form and content set out in instruments emanating from public authorities.

One of the principal changes in the political economy of the global firm concerns the increased access to capital and the greater velocity and volatility of capital movements. Indeed, some observers see changes in capital markets and circuits of capital as the key force driving global economic transformations. This is the point of departure for the article by Gordon L. Clark and Tessa Hebb, which observes a significant reconfiguration of the classic division of labour between shareholders and corporate managers. They argue that pension funds, which are a major source of capital pools, are inevitably moving towards more active corporate engagement in as much as they are seeking to influence company management's decision-making. This stems from what they term as pension fund lock-in; namely, that the increasing recourse to passive indexing in their investment strategies translates into long-term investments in which there is an increased incentive to reduce investment risk by requiring better corporate governance standards, such as accountability and transparency, in the firms in which they invest. At the same time, and closely related, the socially responsible investment movement has been of increasing importance. Clark and Hebb illustrate the new activism of pension funds in their corporate investments and their consequent search for clearer international governance standards for global firms, notably as regards social and environmental performance. This epochal shift in the structure of contemporary capitalism, argue Clark and Hebb, is likely to stimulate yet further this trend towards increased social responsibility as various market actors, whose interests are not always the same, have to agree on new standards of behaviour that govern their conduct. In this sense, the very dynamics of capitalist development are likely to bring forth new actors and institutions to ensure the social regulation of global firms.

The final contribution to this special issue also contests the notion that economic globalization is inevitably characterized by a race to the bottom. Christine Overdevest focuses on private forms of social regulation of the activities of multinational firms in the context of the relative success or 
failure of non-governmental organization (NGO) multi-stakeholder initiatives. Her article traces the competitive dynamics of different corporate codes of conduct and the factors that lead to the diffusion of higher or lower standards of conduct in the competition between these different codes within the same industry. In this detailed study of the international forest sector, she seeks to understand how markets are constructed by economic actors through various forms of horizontal and vertical coordination and how such coordination is essential to the promotion of better practices and higher environmental and labour standards. Horizontal coordination involves competing firms within industry associations agreeing to common standards, so as to reduce any initial risk of early entry into these new standards. Vertical coordination works through supply chains to ensure that these new standards are widely diffused to sub-contracting firms. NGO actors play an important role in this process, as have the competing dynamics between different standards championed by one group or another. While such codes are not a panacea, Overdevest makes the argument that it is necessary to look at the way in which codes permit the coordination between actors and how this coordination is an essential building block for constructing markets in which higher standards of governance and behaviour will be an integral part.

The themes explored in this special issue of $R I / I R$ are of great importance to the development of our thinking about avenues for research on work and employment in a global era. In this new period of economic development, researchers, analysts and actors are engaged in a search for a better balance between the inevitable efficiency outcomes for global firms and the often problematical equity outcomes for workers and their communities. This search is likely to throw up new institutions, actors and regulatory instruments. Their eventual configuration and the links between them are far from evident at this point. In order to understand them better and help guide our research and policy analysis to achieving the social regulation of economic behaviour, our collective research agenda must be particularly sensitive to the reconfiguration of these mechanisms and the emergence of yet other mechanisms for the social regulation of the global firm. Since the foregoing summary hardly does justice to the rich analysis offered in these six contributions, we can only commend our readers to explore the many facets and implications of the themes emerging from this analysis. 


\section{】 REFERENCES}

BANKS, Robert F. and Jack STIEBER, ed. 1977. Multinationals, Unions and Labor Relations in Industrialized Countries. Ithaca: New York State School of Industrial and Labor Relations, Cornell University.

Bartlett, Christopher A. and Sumantra Ghoshal. 2002. Managing Across Borders: The Transnational Solution. Boston: Harvard Business School Press.

DiCKEN, Peter. 2003. Global Shift: Reshaping the Global Economic Map in the $21^{\text {st }}$ Century, $4^{\text {th }}$ edition. London: Sage.

GunTER, Hans, ed. 1972. Transnational Industrial Relations. London and Basingstoke: MacMillan St. Martin' Press.

KujAwA, Duane, ed. 1975. International Labor and the Multinational Enterprise. New York: Praeger Publishers.

World Commission on the Social Dimension of Globalization. 2004. A Fair Globalization: Creating Opportunities for All. Geneva: International Labour Organization. 